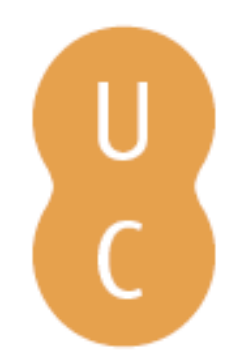

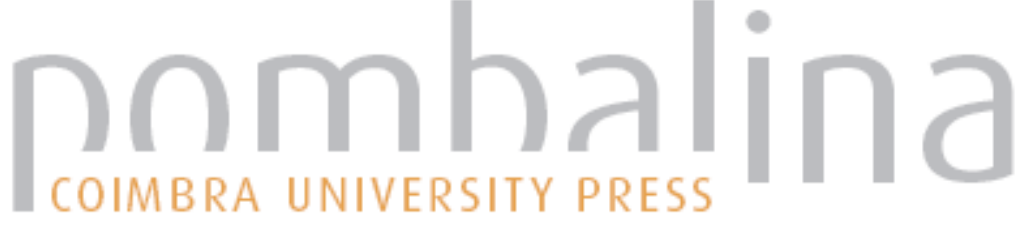

\section{O Estado Novo: (Re)visitando os Manuais de História portugueses}

\author{
Autor(es): $\quad$ Serrano, Clara Isabel \\ Publicado por: Imprensa da Universidade de Coimbra \\ URL \\ persistente: $\quad$ URI:http://hdl.handle.net/10316.2/32212 \\ DOI: $\quad$ DOI:http://dx.doi.org/10.14195/978-989-26-0810-5_16 \\ Accessed : $\quad$ 26-Apr-2023 13:07:11
}

A navegação consulta e descarregamento dos títulos inseridos nas Bibliotecas Digitais UC Digitalis, UC Pombalina e UC Impactum, pressupõem a aceitação plena e sem reservas dos Termos e Condições de Uso destas Bibliotecas Digitais, disponíveis em https://digitalis.uc.pt/pt-pt/termos.

Conforme exposto nos referidos Termos e Condições de Uso, o descarregamento de títulos de acesso restrito requer uma licença válida de autorização devendo o utilizador aceder ao(s) documento(s) a partir de um endereço de IP da instituição detentora da supramencionada licença.

Ao utilizador é apenas permitido o descarregamento para uso pessoal, pelo que o emprego do(s) título(s) descarregado(s) para outro fim, designadamente comercial, carece de autorização do respetivo autor ou editor da obra.

Na medida em que todas as obras da UC Digitalis se encontram protegidas pelo Código do Direito de Autor e Direitos Conexos e demais legislação aplicável, toda a cópia, parcial ou total, deste documento, nos casos em que é legalmente admitida, deverá conter ou fazer-se acompanhar por este aviso.

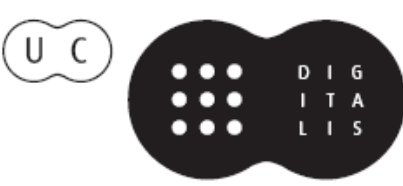




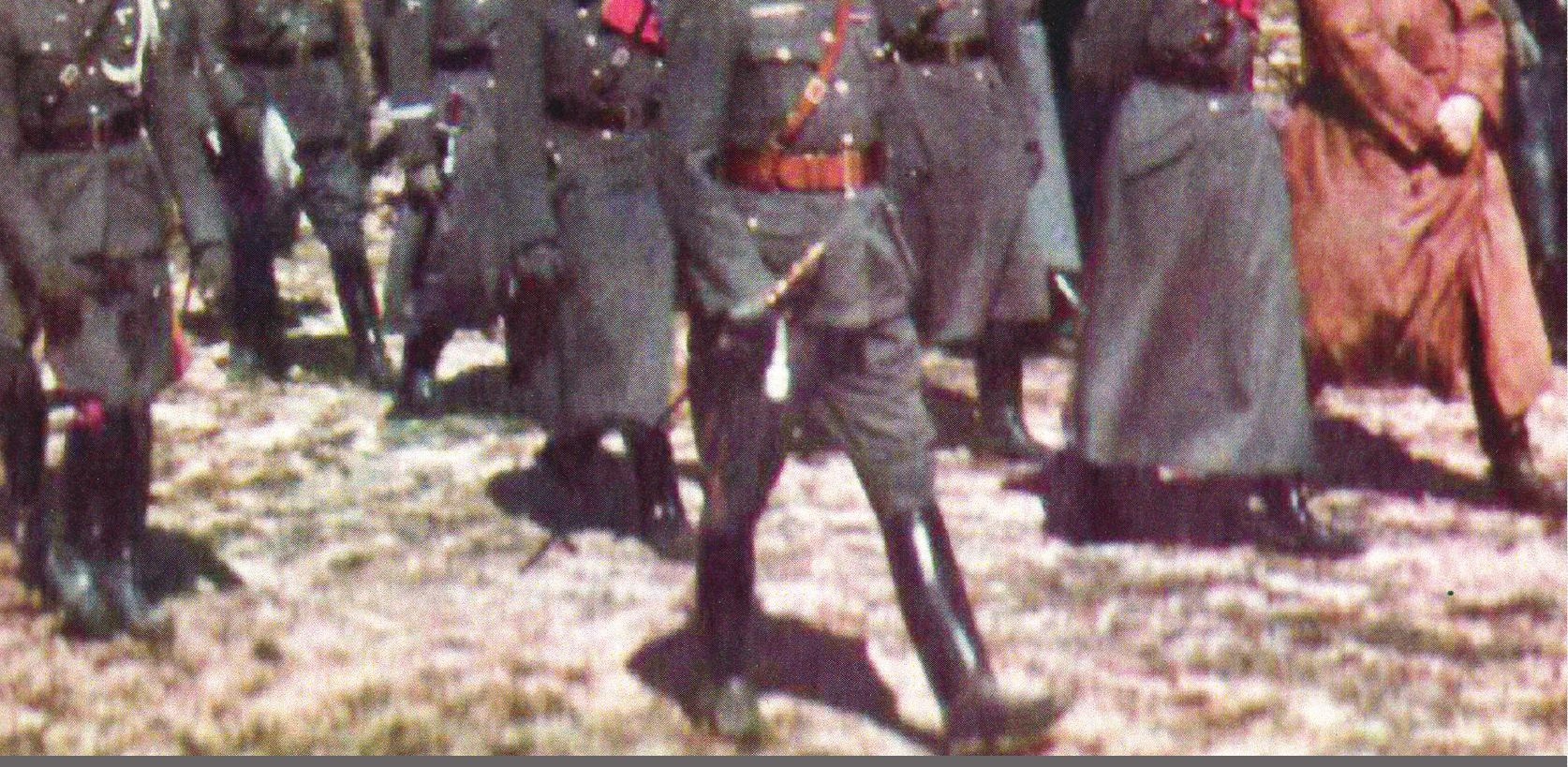

\section{Estados autoritários}

e totalitários

e suas representações

Coordenaação

Luís Reis Torgal

Heloísa Paulo

Coimbra · 2008

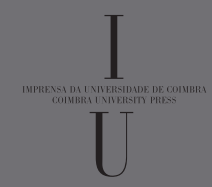




\section{Clara Isabel Serrano}

\section{O ESTADO NOVO: (RE)VISITANDO OS MANUAIS DE HISTÓRIA PORTUGUESES}

\subsection{Catalogação e Análise Quantitativa dos Manuais}

O estudo efectuado abrangeu as disciplinas de História e Geografia de Portugal do sexto ano (segundo ciclo do ensino básico) e de História do nono ano (terceiro ciclo do ensino básico) e do décimo segundo ano de escolaridade (ensino secundário), tendo sido analisados os manuais de cinco editoras. As editoras foram seleccionadas com base nos seguintes critérios:

- As que apresentam uma política editorial da qual resulta a edição de colecções o mais completas possíveis de manuais e guiōes;

- As que se revestem de forte representatividade no mercado para os níveis escolares em consideração.

Os materiais para uso dos alunos foram abrangidos na sua totalidade pela designação de "manuais".

Nos materiais para uso dos professores constatámos uma diversidade de concepções que podem consubstanciar-se em dois modelos distintos:

a) Um modelo corresponde a materiais que, embora tenham em conta o programa da disciplina, são independentes dos manuais existentes, quer a nível de organização dos conteúdos, quer a nível das metodologias, sendo mesmo de autores diferentes. São livros essencialmente concebidos como instrumentos de auto-formação do professor;

b) $\mathrm{O}$ outro modelo abrange materiais que acompanham de perto determinado manual do aluno, ilustrando estratégias a seguir, sugerindo pistas complementares ou alternativas.

Os manuais escolares portugueses, bem como os currículos nacionais ${ }^{1}$, apontam para uma perspectiva de História Universal e Europeia centrada na História de Portugal e, neste caso, há duas formas de apresentar as matérias: tratar algumas estruturas globais

${ }^{1}$ Vide Currículo Nacional do Ensino Básico. Competências Essenciais, Lisboa, Ministério da Educação, Departamento da Educação Básica, 2001, p. 102. 
a partir da História Nacional ou tratar as conjunturas europeias, onde se insere a análise do caso português, que se destaca pela sua especificidade ${ }^{2}$ (e mostram uma Europa constituída por naçôes que se desenvolvem num mundo político, económico e cultural diversificado, embora com traços comuns) ${ }^{3}$. Ou seja, a dimensão europeia é introduzida de forma a esclarecer a História Nacional e/ou mostrar o contributo (decisivo) que um ou vários países deu ou deram à História da Europa.

O estudo do Estado Novo encontra-se incluído no programa oficial da disciplina de História e Geografia de Portugal do sexto ano, no tema "O Século XX", no segundo subtema "O Estado Novo" ${ }^{4}$. No programa do nono ano de escolaridade está inserido no tema dez "Da Grande Depressão à Segunda Guerra Mundial”, no segundo subtema "Entre a Ditadura e a Democracia", na rubrica "Portugal: a ditadura salazarista" e no tema onze "Do Segundo Após-Guerra aos Anos Oitenta", no terceiro subtema "Portugal: do autoritarismo à democracia" ${ }^{5}$. No programa do décimo segundo ano 6 está inserido no módulo oito "Portugal e o Mundo da Segunda Guerra Mundial ao Início da Década de 80 - Opções Internas e Contexto Internacional”, no segundo tema "Portugal do autoritarismo à democracia" .

Com as sucessivas reformas curriculares introduzidas regista-se uma visível diminuição do tempo e do espaço dedicados ao estudo da História, em geral e, ao Estado Novo, em particular ${ }^{8}$. Para formarmos uma ideia muito clara do assunto bastará dizer que, das duzentas e quarenta páginas que em média os manuais portugueses do nono ano de escolaridade têm, apenas trinta e cinco páginas, ou seja, 14,5\% do manual, são dedicadas ao Estado Novo. Ademais, podemos constatar que nestas proliferam as ilustraçôes e as actividades.

Nos manuais portugueses pode-se ainda verificar um processo evolutivo muito claro no que toca à correlação entre os textos propostos pelos autores, os documentos históricos incorporados e as actividades propostas aos alunos. A evolução consiste numa

\footnotetext{
2 Ana Henggler, "O Ensino da História de Portugal: Um Estudo Comparativo (1936, 2000)" in Ensino da História, Lisboa, III série, n. ${ }^{o}$ 18, Associação de Professores de História/A: P: H:, Outubro de 2000, p. 63.

${ }^{3}$ António Simões Rodrigues, "Um manual de História da Europa. A construção de uma utopia?” in: Estudos do Século XX, Europa-Utopia/Europa-Realidade, n.o 2, CEIS 20, coord. de Maria Manuela Tavares Ribeiro, Coimbra, Quarteto Editora, 2002, p. 216.

${ }^{4}$ Vide Fátima Costa, António Marques, História e Geografia de Portugal 6. ${ }^{\circ}$ ano, Porto, Porto Editora, 2005 , p. 3.

5 Vide Programa História, Plano de Organização de Ensino-Aprendizagem, Ensino Básico, 3. ${ }^{\circ}$ Ciclo, volume II, 3. ${ }^{a}$ edição, Lisboa, DGEBS/INCM, 1994, pp. 71 - 72 e 77.

${ }^{6} \mathrm{O}$ programa de História A do décimo segundo ano de escolaridade entrou em vigor no ano lectivo de 2005/2006, no quadro do Decreto-Lei n. ${ }^{\circ} 286 / 89$, de 29 de Agosto, que estabelece os princípios gerais da estruturação curricular dos ensinos básico e secundário, estando apenas em vigor os aspectos respeitantes ao ensino secundário, e em turmas residuais.

7 Vide Clarisse Mendes (coord. de), Cristina Silveira, Margarida Brum, Programa de História A. 10. ${ }^{\circ}$, $11 .^{\circ}$ e 12. ${ }^{\circ}$ Anos. Curso Científico - Humanístico de Ciências Sociais e Humanas. Formação Específica, Lisboa, Ministério da Educação/Departamento do Ensino Secundário, 2002, pp. 53 - 55.

${ }^{8}$ A diminuição da carga horária é visível na mudança de cento e oitenta minutos para os actuais cento e trinta e cinco ou até mesmo noventa minutos semanais que a disciplina de História tem no segundo e no terceiro ciclos do ensino básico.
} 
presença cada vez mais reduzida do texto em benefício das imagens, da transcrição de documentos e da multiplicação de actividades.

Estas transformaçôes no conteúdo e na forma dos manuais devem-se a uma pressão cada vez maior dos currículos oficiais, que conferem ao professor e ao manual o papel de guia na aprendizagem activa dos alunos. Esta tendência conduz, em alguns casos, a uma certa forma de "activismo pedagógico" de duvidosa coerência com os preceitos curriculares oficiais, explicitamente comprometidos com a interiorização progressiva de um ethos científico-investigador por parte dos estudantes do terceiro ciclo do ensino básico e do ensino secundário. Por outras palavras, o tornar os manuais mais apelativos através da proliferação de imagens ou menos fastidiosos para as turmas devido à abundância de actividades heterogéneas, não contribui necessariamente para o desenvolvimento do "espírito científico". Em certas ocasiōes, há que dizê-lo, as actividades propostas pelos manuais e desenvolvidas nas aulas parecem ter mais de lúdico do que de didáctico.

\subsection{O Estado Novo nos Manuais de História}

Com a inclusão deste tema nos manuais, pretende-se que os discentes:

- conheçam "as condições de institucionalização do "Estado Novo" em Portugal, destacando o papel de Salazar nesse processo"9;

- caracterizem o "Estado Novo" nas suas dimensões repressiva, conservadora, corporativa e colonial" 10 ;

- "expliquem as condiçôes que conduziram nos anos 50 e 60 à aplicação de medidas de fomento industrial e à abertura aos capitais estrangeiros" ${ }^{11}$;

- "relacionem a estagnação da agricultura com a afluência de população aos grandes centros urbanos e com a fortíssima emigração" 12 ;

- "compreendam as razōes da oposição interna ao regime e conheçam figuras e factos relacionados com essa oposição" ${ }^{13}$;

- "expliquem a eclosão, em Angola, em Moçambique e na Guiné, de movimentos armados a favor da independência, reconhecendo os pesados custos humanos e materiais da guerra colonial" 14 ;

- "identifiquem o marcelismo como uma tentativa de democratização do regime, feita a partir do seu interior e tornada impossível pelas contradiçóes dos grupos de apoio a esse regime" ${ }^{15}$;

9 Programa História, Plano de Organização de Ensino-Aprendizagem, Ensino Básico, 3.o Ciclo, volume II, 3. a edição, Lisboa, DGEBS/INCM, 1994, p. 71.

${ }^{10}$ Idem, ibidem.

11 Idem, ibidem.

12 Idem, ibidem.

13 Idem, ibidem.

${ }^{14}$ Idem, ibidem.

15 Idem, ibidem. 
- "conheçam as razôes que levaram sectores importantes das Forças Armadas a revoltarem-se contra o regime, em 25 de Abril de 1974, explicando o apoio popular a esse movimento e caracterizando o processo revolucionário que então se desencadeia"16;

- "compreendam o significado da democratização tornada possível com o 25 de Abril, identificando as principais instituiçôes democráticas e sublinhando a importância para as populaçóes da dinamização do poder autárquico e da criação das regiōes autónomas" ${ }^{17}$;

- "conheçam as circunstâncias em que se processou a descolonização e algumas das suas consequências, nomeadamente a necessidade de integração em Portugal de centenas de milhares de nacionais regressados ao país num curto espaço de tempo" 18 ;

- "destaquem a interacção entre a política interna e externa dos Estados, e o seu condicionamento por factores geoestratégicos"19;

- "realcem a profundidade da ruptura operada pela Revolução de Abril na sociedade portuguesa, bem como o seu impacto internacional" ${ }^{20}$;

- "evidenciem as transformações socioculturais do terceiro quartel do século, quer ampliando tendências já desenhadas no período anterior, quer anunciando mudanças que se afirmarão a partir dos anos oitenta" ${ }^{21}$.

Em termos gerais a abordagem do tema obedece a um esquema convencional:

- A edificação do Estado Novo: os manuais escolares referem a nomeação de António de Oliveira Salazar para ministro das Finanças em 1928, para Presidente do Conselho em 1932, a criação das "bases do regime, nomeadamente o partido único e a nova Constituição" 22 , o desenvolvimento de rigorosos mecanismos repressivos, como a polícia política e a censura, a criação da Legião e da Mocidade Portuguesas e a organização da vida económica e social do país em corporações.

- Proteccionismo e colonialismo: é dado grande destaque à intervenção preconizada pelo Estado Novo do Estado na economia, através de uma política de proteccionismo e de dirigismo. Sendo assim, são destacados os incentivos à indústria nacional, a campanha do trigo iniciada em 1929 e o incremento da política de obras públicas. Os manuais salientam ainda a importância das colónias, consideradas um elemento fundamental da política de nacionalismo económico. Destacam

16 Idem, ibidem.

${ }^{17}$ Programa História, Plano de Organização de Ensino-Aprendizagem, Ensino Básico, 3. ${ }^{\circ}$ Ciclo, volume II, 3. a edição, Lisboa, DGEBS/INCM, 1994, pp. 77-78.

18 Idem, ibidem.

19 Idem, ibidem.

${ }^{20}$ Idem, ibidem.

${ }^{21}$ Clarisse Mendes (coord. de), Cristina Silveira, Margarida Brum, Programa de História A. 10. ${ }^{\circ}, 11 .^{\circ}$ e 12. ${ }^{\circ}$ Anos. Curso Cientifico - Humanístico de Ciências Sociais e Humanas. Formação Específica, Lisboa, Ministério da Educação/Departamento do Ensino Secundário, 2002, p. 53.

${ }^{22}$ Maria Emília Diniz, Adérito Tavares, Arlindo M. Caldeira, História 9, 1.a ed., Lisboa, Editorial O Livro, 2000, p. 124. 
a aprovação do Acto Colonial, logo em 1930, salientando a sua inclusão, mais tarde, na Constituição de 1933. Referem ainda que, para além do seu papel económico, o Império Colonial foi também utilizado pelo Estado Novo como um dos principais temas da propaganda nacionalista, sendo considerado, pela riqueza e extensão dos seus territórios, uma das provas da grandeza de Portugal.

- O tardio desenvolvimento económico: os manuais referem, após o fim da Segunda Guerra Mundial, o atraso económico do país. Mais de metade da população activa trabalhava no sector primário. Para combater a estagnação, destacam a adopção de um novo modelo de desenvolvimento, no início dos anos 50, que privilegiava a industrialização, ainda que submetida a rigorosas regras de condicionamento industrial. Conferem grande destaque aos planos de fomento, ao ambicioso plano hidroeléctrico nacional, mas também à entrada de investimentos estrangeiros, a partir dos anos 60, devido à aproximação a outros países da Europa e à integração na EFTA. O crescimento económico registado era, no entanto, insuficiente para que o país recuperasse do atraso que o separava dos países mais desenvolvidos. Esta situação de atraso deu origem a um excepcional movimento migratório, quer para os principais centros urbanos portugueses, quer para o estrangeiro, o que conduziu a um despovoamento, a partir dos anos 60 , de certas regióes do país, em especial do interior norte.

- A oposição: os livros escolares destacam que, apesar da repressão, o Estado Novo nunca deixou de ser contestado. A principal força política organizada, ainda que na clandestinidade, era o Partido Comunista, que dispunha de grande influência nos meios operários e entre os camponeses do Alentejo. Consideram que foi igualmente activa a corrente filiada nos ideais republicanos e socialistas, que contava entre si muitos intelectuais e elementos das profissões liberais. As eleições de 1945, as eleições presidenciais de 1949 e de 1958 são consideradas, unanimemente por todos os manuais analisados, momentos de forte oposição ao regime. A actuação violenta e arbitrária da Polícia nestas três ocasióes e em algumas greves e manifestações de protesto revela, de acordo com os manuais, um endurecimento do regime ditatorial, que se sentia cada vez mais ameaçado e contestado. Não obstante, não deixou de se afirmar uma literatura de resistência e muitos intelectuais prestigiados e até mesmo elementos da hierarquia católica condenavam energicamente o regime, insistindo na necessidade do país se democratizar. Todavia, às críticas, o regime respondia com a prisão ou o exílio.

- A guerra colonial: os manuais consideram que, à semelhança do que acontece com outros países, também nas colónias portuguesas surgem movimentos nacionalistas, cujas bases se aglutinam mais por motivos étnicos do que por interesses económicos ou princípios políticos. O Acto Colonial de 1930, reforçado posteriormente com a revisão constitucional de 1951, substituindo o conceito de colónia pelo de província ultramarina, constituía o documento fundamental da política ultramarina portuguesa. O novo conceito de "província ultramarina" levantou forte polémica entre a comunidade internacional, sobretudo após a entrada de Portugal na ONU, em 1955, mas serviu sempre de justificação ao governo português para não fornecer informações sobre as suas "colónias", como estipulava o artigo $73 .^{\circ}$ da Carta das Nações Unidas e para recusar o auxílio norte-americano, no sentido da resolução do futuro do ultramar português. A 
inflexibilidade do regime de Salazar, cada vez mais isolado internacionalmente na defesa da sua posição, levou a inevitáveis confrontos nas colónias: Índia e Angola, 1961; Guiné, 1963; e Moçambique, 1964. A decisão de Salazar de defender intransigentemente as "províncias ultramarinas" exigiu ao país um enorme esforço humano e económico. No entanto, teve um efeito estimulante sobre a economia das colónias, uma vez que estas foram dotadas de novas infraestruturas e receberam inúmeros investimentos estrangeiros.

- O marcelismo: os manuais referem que, devido a uma grave doença, António de Oliveira Salazar acabaria por se afastar em 1968, sendo substituído por Marcelo Caetano. Numa primeira fase, Marcelo Caetano procedeu a uma descompressão política, aliviando a repressão policial, aligeirando a actuação da censura e permitindo o regresso de alguns exilados políticos. No entanto, em 1969, aquando das eleiçōes para a Assembleia Nacional, a oposição viu as suas expectativas defraudadas. "O marcelismo parecia esquecer as promessas de renovação e apostava na continuidade" 23 . Mantinha-se o desrespeito pelos direitos e liberdades individuais, a polícia política e a censura voltavam a actuar com dureza e violência. A economia crescia, fruto da aceleração da industrialização e da abertura ao investimento estrangeiro. Em termos sociais, os livros escolares destacam, como maiores realizações do marcelismo, o alargamento da previdência às populações rurais e o início da reforma educativa (dita de Veiga Simão). Todavia, apesar destas reformas, o regime ditatorial continuava a suscitar grande descontentamento. A luta intensificava-se e o regime agonizava, conduzido a um verdadeiro beco sem saída pela questão fundamental do país, a guerra colonial. Em 1973, a guerra na Guiné estava praticamente perdida e encontrava-se num impasse em Angola e Moçambique. Perante a falência da solução militar e a recusa da solução política, a questão ultramarina acabaria por ser resolvida através de uma revolução - a revolução de 25 de Abril de 1974 .

\section{3. Figuras Históricas}

Os manuais analisados referem as principais figuras históricas deste período. A mais destacada é, sem dúvida, a de António de Oliveira Salazar (1889-1970), estadista, político, professor da Universidade de Coimbra, chefe do Governo entre 1932 e 1968, fundador e principal ideólogo do Estado Novo, a mais longa ditadura da Europa Ocidental no século XX, com 26,2\% das referências dos livros escolares. Estes destacam, ainda, Marcelo Caetano (1906-1980), jurista, doutrinador, dirigente político e último chefe do Governo do Estado Novo.

Não esquecem os Presidentes da República deste período, como António Óscar de Fragoso Carmona (1869-1951), primeiro Presidente da República durante a vigência constitucional do Estado Novo; Francisco Higino Craveiro Lopes (1894-1964), marechal, Presidente entre 1951 e 1958; e Américo Tomás (1894-1987), Presidente entre 1958 e 1974.

${ }^{23}$ Maria Emília Diniz, Adérito Tavares, Arlindo M. Caldeira, História 9, 1.a ed., Lisboa, Editorial O Livro, 2000, p. 238. 
Os manuais observados referem, outrossim, alguns dos ministros e secretários de Estado Novo, como Adriano Moreira (n. 1922), jurista, figura destacada da política a partir dos anos 60, ministro do Ultramar entre 1961 e 1963; Júlio Botelho Moniz (1900-1970), general, ministro do Interior de 1944 a 1947, ministro da Defesa Nacional entre 1958 e 1961, líder do golpe de Estado militar a "Abrilada", que, em Abril de 1961, envolveu quase toda a hierarquia militar e que contava com o apoio do ex-presidente Craveiro Lopes para afastar Salazar do poder; Diogo Pinto de Freitas do Amaral (n. 1941), político, professor universitário, um dos tecnocratas que personifica o novo rosto do regime; Duarte Pacheco (1899-1943), engenheiro que ocupou por duas vezes o cargo de ministro das Obras Públicas e Comunicações, função que acumulou, a partir de 1938, com a presidência da Câmara Municipal de Lisboa; Ferreira Dias (1900-1966), engenheiro, grande impulsionador da electrificação e da industrialização do país, ministro da economia entre 1958 e 1962; João Maurício Fernandes Salgueiro (n. 1934), economista, político, subsecretário de Estado do Planeamento entre 1969 e 1971; Maria de Lurdes Ruivo da Silva Pintassilgo (1930-2004), engenharia, Procuradora na Câmara Corporativa; Rogério Martins (1965-1974), secretário de Estado do Ministério da Economia, que integrou o chamado "grupo dos liberais" durante a "primavera marcelista"; Valentim Xavier Pintado (n. 1925), secretário de Estado do Ministério da Economia, que integrou o chamado "grupo dos liberais" durante a "primavera marcelista"; e Veiga Simão (n. 1929), político, ministro da Educação Nacional entre 1970 e 1974.

Os manuais referem igualmente alguns dos militares mais importantes da época como o marechal António de Spínola (1910-1996), governador e comandante-chefe das Forças Armadas da Guiné (1968-1973), vice-chefe do Estado-Maior-General das Forças Armadas (1974) e primeiro Presidente da República do regime saído da revolução de 25 de Abril (15 de Maio e 30 de Setembro de 1974); Francisco da Costa Gomes (1914-2001), marechal, comandante da Região Militar de Moçambique entre 1967 e 1969, comandante-chefe da Região Militar de Angola entre 1970 e 1972, chefe do Estado-Maior General das Forças Armadas entre 1972 e 1974, chefe de Estado entre 1974 e 1976; e Manuel António Vassalo e Silva (1899-1985), brigadeiro, último governador-geral do Estado Português da Índia.

Ao longo do estudo do Estado Novo, os manuais aludem às diversas personalidades que se opuseram ao regime como Álvaro Cunhal (1913-2005), político e escritor, secretário-geral do Partido Comunista Português entre 1961 e 1992; Alves Redol (1911-1969), escritor, membro do Movimento de Unidade Democrática (MUD), que se opunha ao regime do Estado Novo e do Partido Comunista Português; D. António Ferreira Gomes (1906-1989), bispo da Diocese do Porto entre 1952 e 1982; António Sérgio (1883-1969), ensaísta, vice-presidente da junta consultiva do MUD em 1946 e dirigente do Directório Democrato-Social nos anos 50; Aquilino Ribeiro (1885-1967), escritor; Arlindo Vicente (1906-1990), advogado, pintor, candidato às eleições presidenciais de 1958; Bento de Jesus Caraça (1901-1948), matemático, professor catedrático, militante do Partido Comunista Português; Egas Moniz (18741955), médico, professor catedrático, Prémio Nobel da medicina em 1949; Fernando Lopes Graça (1906-1994), compositor; Henrique Galvão (1895-1970), capitão do exército, explorador-naturalista, escritor que ficou mundialmente famoso, em 1961, por ter organizado e comandado o assalto ao paquete "Santa Maria"; Humberto 
Delgado (1906-1965), militar português da Força Aérea que corporizou o principal movimento de tentativa de derrube da ditadura salazarista através de eleiçôes, tendo contudo sido derrotado nas urnas; Jaime Cortesão (1884-1960), médico, político, escritor e historiador; João Abel Manta (1888-1982), pintor; José Magalhães Godinho (1909-1994), advogado, republicano, socialista, promotor do Movimento de Unidade Democrática (MUD); Manuel Alegre (n. 1936), poeta e político; Maria Helena Vieira da Silva (1908-1992), pintora; Mário Soares (n. 1924), político, fundador do Partido Socialista de Portugal em 19 de Abril de 1973, Primeiro-ministro de Portugal entre 1976 e 1977, em 1978 e entre 1983 e 1985 e Presidente da República entre 1986 e 1996; Norton de Matos (1867-1955), general, político, candidato às eleiçôes presidenciais de 1949; Hermínio Palma Inácio (n. 1922), militar, dirigiu o desvio do avião da TAP da carreira Casablanca - Lisboa, a 10 de Novembro de 1961, considerado o primeiro caso de pirataria área internacional, membro da Liga de Unidade e Acção Revolucionária (LUAR); Pulido Valente (n. 1941), historiador e comentador político; Rolão Preto (1896-1977), militar, político, conspirador na tentativa golpe de Estado contra Salazar em 1935; Rui Luís Gomes (1905-1984), matemático, professor universitário e investigador, candidato à Presidência da República em 1951; Francisco Salgado Zenha (1923-1993), advogado, político, membro do Partido Comunista Português; Soeiro Pereira Gomes (1909-1949), escritor, militante comunista; e Zeca Afonso (1929-1987), cantor e compositor.

Os compêndios portugueses não esquecem os fundadores dos movimentos de libertação das "províncias ultramarinas" como António Agostinho Neto (1922-1979), médico, político, primeiro Presidente da República Popular de Angola e considerado um dos membros fundadores do Movimento Popular de Libertação de Angola (MPLA) e do Movimento Anticolonial (MAC); Amílcar Cabral (1924-1973), engenheiro, fundador do Partido Africando da Independência (PAI), que a partir de Outubro de 1960 passou a designar-se Partido Africano da Independência da Guiné e Cabo Verde (PAIGC); Eduardo Mondlane (1924-1969), antropólogo, sociólogo, fundador da Frente de Libertação de Moçambique (FRELIMO); Holden Roberto (1923-2007), político angolano, líder do movimento União das Populações de Angola (UPA); Jonas Savimbi (1934-2002), político angolano, líder durante mais de trinta anos da UNITA; Mário de Andrade (1928-1990), político e intelectual angolano, membro do grupo que está na origem do MPLA; e Samora Machel (1933-1986), líder militar da FRELIMO e Presidente do Estado de Moçambique entre 1975 e 1986.

Nos manuais estudados são referidos também alguns dos políticos, adeptos de uma liberalização do regime e que formam a chamada "ala liberal" da Assembleia Nacional como Francisco Manuel Lumbrales de Sá Carneiro (1934-1980), político português, fundador e líder do Partido Popular Democrático/Partido Social-Democrata, e ainda primeiro-ministro de Portugal, durante cerca de onze meses, no ano de 1980, advogado de profissão, formado na Faculdade de Direito da Universidade de Lisboa, eleito pelas listas da Acção Nacional Popular, para a Assembleia Nacional, onde se converteu em líder da Ala Liberal; Francisco Pinto Balsemão, (n. 1937), empresário, advogado, jornalista, deputado à Assembleia da República, Primeiro-ministro dos VII e VIII Governos Constitucionais, militante do Partido Social-democrata (PSD); João Pedro Miller Pinto de Lemos Guerra (1912-1990), médico, membro da chamada Ala Liberal da Assembleia da República, que abriu caminho às transformaçōes democráticas que 
a Revolução de 25 de Abril preconizaria; e Joaquim Jorge Magalhães Mota (n. 1935), militante do Partido Social-democrata (PSD), que criou no pós 25 de Abril, com Francisco Pinto Balsemão e Sá Carneiro.

Os manuais aludem ainda ao Cardeal D. Manuel Gonçalves Cerejeira (1888-1977), décimo - quarto Patriarca de Lisboa, nomeado em 18 de Novembro de 1929, apoiante do Estado Novo e a algumas personalidades internacionais como Benito Mussolini (1883-1945), político italiano; Léopold Sédar Senghor (1906-2001), político e escritor senegalês, presidente da nova República de 1960 a 1980; e Paulo VI (1897-1978), Papa de 1963 a 1978, chefe da Igreja Católica durante a maior parte do Concílio Vaticano II, decisivo na colocação em prática das suas decisões.

\begin{tabular}{|l|c|}
\hline \multicolumn{1}{|c|}{ Figuras históricas } & Percentagem \\
\hline \multicolumn{1}{|c|}{${ }^{24}$} \\
\hline Adriano Moreira & $0,6 \%$ \\
\hline Álvaro Cunhal & $0,6 \%$ \\
\hline Américo Tomás & $3,5 \%$ \\
\hline Amílcar Cabral & $2,3 \%$ \\
\hline António Agostinho Neto & $0,6 \%$ \\
\hline António Alves Redol & $0,6 \%$ \\
\hline António Caetano de Abreu Freire Egas Moniz & $0,6 \%$ \\
\hline António de Oliveira Salazar & $26,2 \%$ \\
\hline António de Spínola & $4,1 \%$ \\
\hline António Ferreira Gomes & $2,3 \%$ \\
\hline António Óscar de Fragoso Carmona & $1,8 \%$ \\
\hline António Sérgio de Sousa & $1,8 \%$ \\
\hline Aquilino Ribeiro & $0,6 \%$ \\
\hline Arlindo Vicente & $0,6 \%$ \\
\hline Benito Mussolini & $0,6 \%$ \\
\hline Bento de Jesus Caraça & $0,6 \%$ \\
\hline Diogo Freitas do Amaral & $0,6 \%$ \\
\hline Duarte Pacheco & $0,6 \%$ \\
\hline Eduardo Mondlane & $1,2 \%$ \\
\hline Fernando Lopes Graça & $1,2 \%$ \\
\hline Francisco da Costa Gomes & $1,8 \%$ \\
\hline Francisco de Sá Carneiro & $2,3 \%$ \\
\hline Francisco Higino Craveiro Lopes & $0,6 \%$ \\
\hline Francisco Pinto Balsemão & $0,6 \%$ \\
\hline Francisco Rolão Preto & $0,6 \%$ \\
\hline Francisco Salgado Zenha & $1,2 \%$ \\
\hline Henrique Galvão & $0,6 \%$ \\
\hline Hermínio Palma Inácio & $0,6 \%$ \\
\hline Holden Roberto & $1,2 \%$ \\
\hline Humberto Delgado & $6,4 \%$ \\
\hline Jaime Cortesão & $1,2 \%$ \\
\hline João Abel Manta & $0,6 \%$ \\
\hline & \\
\hline & \\
\hline
\end{tabular}

${ }^{24}$ Registe-se que os dados provêem da análise de cento e setenta e uma referências em dezoito manuais escolares dos sexto, nono e décimo segundo anos de escolaridade. 


\begin{tabular}{|c|c|}
\hline Figuras históricas & Percentagem $^{24}$ \\
\hline João Pedro Miller Guerra & $0,6 \%$ \\
\hline João Salgueiro & $0,6 \%$ \\
\hline Joaquim Jorge Magalhães Mota & $0,6 \%$ \\
\hline Joaquim Soeiro Pereira Gomes & $0,6 \%$ \\
\hline Jonas Savimbi & $1,2 \%$ \\
\hline José Magalhães Godinho & $0,6 \%$ \\
\hline José Manuel Afonso dos Santos & $0,6 \%$ \\
\hline José Maria Mendes Ribeiro Norton de Matos & $1,2 \%$ \\
\hline José Nascimento Ferreira Dias Júnior & $0,6 \%$ \\
\hline José Veiga Simão & $1,2 \%$ \\
\hline Júlio Botelho Moniz & $1,2 \%$ \\
\hline Léopold Senghor & $1,2 \%$ \\
\hline Manuel Alegre & $0,6 \%$ \\
\hline Manuel António Vassalo e Silva & $1,2 \%$ \\
\hline Manuel Gonçalves Cerejeira & $0,6 \%$ \\
\hline Marcelo Caetano & $9,2 \%$ \\
\hline Maria de Lurdes Pintassilgo & $0,6 \%$ \\
\hline Maria Helena Vieira da Silva & $0,6 \%$ \\
\hline Mário de Andrade & $0,6 \%$ \\
\hline Mário Soares & $2,9 \%$ \\
\hline Oliveira Martins & $1,2 \%$ \\
\hline Paulo VI, Papa & $0,6 \%$ \\
\hline Rogério Martins & $0,6 \%$ \\
\hline Rui Luís Gomes & $0,6 \%$ \\
\hline Samora Machel & $0,6 \%$ \\
\hline Valentim Xavier Pintado & $0,6 \%$ \\
\hline Vasco Pulido Valente & $0,6 \%$ \\
\hline
\end{tabular}

Alguns manuais analisados incluem pequenas biografias ou notas biográficas de António de Oliveira Salazar, de Duarte Pacheco, de Humberto Delgado e de Marcelo Caetano.

\subsection{Documentos Iconográficos}

Os manuais de História hoje utilizados consagram um espaço extremamente importante a imagens, gráficos, mapas, tabelas e barras cronológicas ${ }^{25}$. Este atinge uma percentagem muito próxima dos $50 \%$ nos manuais escolares do nono ano, valor esse que tende a baixar quando analisamos os manuais de História do décimo segundo ano de escolaridade.

Regista-se ainda um aumento progressivo do uso da cor nas imagens, nos mapas, nas tabelas e nas barras cronológicas nas duas últimas décadas, em substituição do preto e branco, muito em voga até à década de oitenta.

${ }^{25}$ Nos manuais analisados $75 \%$ dos documentos são iconográficos e $25 \%$ são escritos. 
As imagens que tendem a surgir nos manuais são as dos grandes heróis e personagens históricas, dos grandes feitos, prioritariamente os bélicos, mas também cenas da vida cultural e quotidiana. Cabe também destacar a progressiva presença de caricaturas, de cartazes, de propaganda política e fotografias de objectos e instrumentos procedentes de diferentes tipos de museus.

No que concerne à análise dos documentos iconográficos relativos ao Estado Novo, verifica-se um predomínio da fotografia, como se pode comprovar pelo seguinte quadro:

\begin{tabular}{|l|c|}
\hline \multicolumn{1}{|c|}{ Documentos iconográficos } & Percentagem \\
\hline Fotografias & $48 \%$ \\
\hline Cartazes & $20 \%$ \\
\hline Quadros & $9 \%$ \\
\hline Gráficos & $7 \%$ \\
\hline Caricaturas & $6 \%$ \\
\hline Mapas & $4 \%$ \\
\hline Postais & $2 \%$ \\
\hline Cronologias & $1 \%$ \\
\hline Desenhos & $1 \%$ \\
\hline Esquemas & $1 \%$ \\
\hline Ilustraçôes & $1 \%$ \\
\hline
\end{tabular}

Pela análise do quadro conclui-se que os autores dos manuais dão prioridade à utilização da fotografia, sendo que as que surgem com maior frequência são as da guerra colonial, de António de Oliveira Salazar, de trabalhadores em protesto, do embarque de tropas portuguesas para África, de Francisco de Sá Carneiro e da campanha de Humberto Delgado para as eleiçôes presidenciais de 1958. De salientar ainda a inclusão de um elevado número de cartazes, sobretudo de propaganda (económica, política, eleitoral, turística, colonial...) do Estado Novo, quadros, gráficos e caricaturas, todas da autoria de João Abel Manta, que visam tornar mais fácil a compreensão dos assuntos expostos.

\subsection{Documentos Escritos}

Os manuais escolares valem-se frequentemente dos documentos escritos para ilustrar assuntos expostos, fornecer informaçōes mais específicas sobre determinadas matérias, apresentar o pensamento ou discurso de personagens ou historiadores e expor a opinião dos contemporâneos, mormente através do recurso a artigos de imprensa. Nos livros analisados $25 \%$ dos documentos apresentados são escritos. Destes, destacam-se claramente os discursos e entrevistas de Salazar, que constituem 21\% dos documentos escritos e o Hino Legionário de 1937, que representa cerca de 7\%. Para além destes surgem ainda outros documentos, como se pode verificar pelo quadro que se segue: 


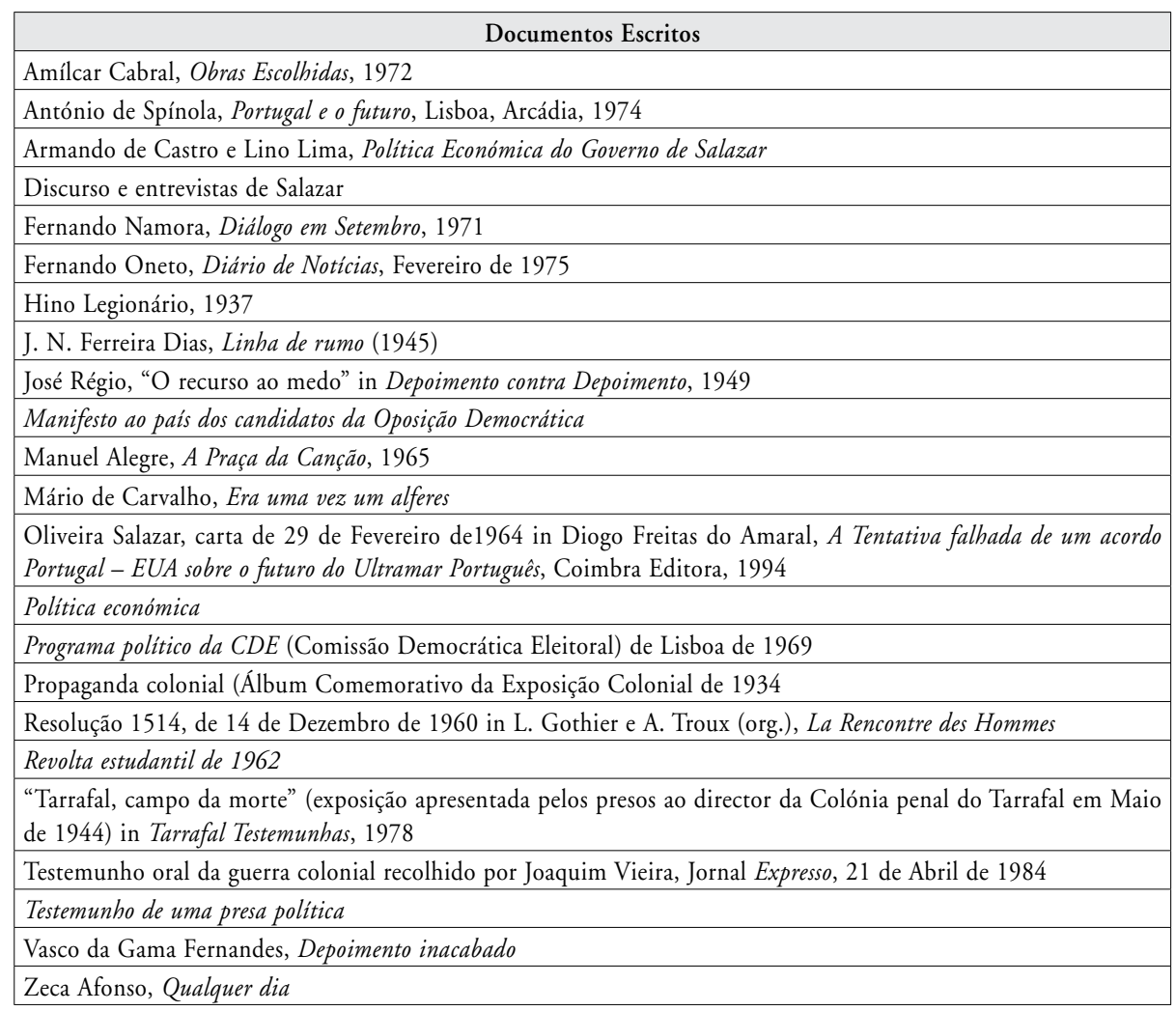

\subsection{Orientações didácticas}

Como já referimos, os manuais de História são instrumentos pedagógicos inseparáveis das condições e dos métodos de ensino de cada época. Por isso, reflectem as tradições, as inovaçôes e até mesmo as utopias pedagógicas e didácticas do seu tempo. Por um lado e, dentro de uma concepção clássica, os manuais são depositários dos conhecimentos, cuja aquisição a sociedade julga necessária para a perpetuação dos seus valores. Por outro, os manuais procuram reflectir concepções metodologicamente mais ricas e activas do processo de ensino e de aprendizagem. A inclusão de numerosos documentos escritos, que devem ser analisados pelos alunos, bem como as questões formuladas exemplificam esta perspectiva.

Apesar de o Currículo $\mathrm{Nacional}^{26}$, que se pretende aberto e flexível, ser bastante generalista na definição dos conteúdos a leccionar, sugerir uma abordagem sucinta

${ }^{26}$ Currículo Nacional do Ensino Básico. Competências Essenciais, Lisboa, Ministério da Educação, Departamento da Educação Básica, 2001. 
de alguns temas ${ }^{27}$ e omitir outros ${ }^{28}$, os manuais acabam por ser pouco selectivos na hora da escolha, pois contemplam e especificam todos os conteúdos que fazem parte dos programas em vigor ${ }^{29}$.

No entanto, tanto o Currículo Nacional como os manuais chamam a atenção para a autonomia que o professor tem para gerir os conteúdos a reger no quadro da escola em que se insere e em função das características da turma.

No que concerne às principais características didácticas dos manuais e, começando pelos textos redigidos pelos seus autores, estes seguem um tipo expositivo e orientamse pela mesma interpretação a respeito de um determinado acontecimento histórico. Não há pluralidade de interpretações, nem recurso a opiniōes de outros autores ou historiadores.

Outro dado interessante é o facto dos manuais incluírem um número cada vez mais significativo de documentos escritos e iconográficos, mapas, tabelas, gráficos e barras cronológicas para análise dos alunos.

Ocorre ainda chamar a atenção para as tarefas, as questôes e as fichas de trabalho que estão presentes em todos os manuais e nos cadernos de actividades que os acompanham, de forma interrogativa e que se propóem, na sua maioria, a serem resolvidas individualmente pelos alunos, embora também surjam sugestôes de trabalho em grupo ou para toda a turma.

O tipo de questões mais frequente é aquele que visa desenvolver a capacidade de aplicar conhecimentos. Podem servir como exemplo as seguintes:

- Identificar os objectivos da educação no Estado Novo ${ }^{30}$.

- Indicar de que modo o Estado Novo limitou a "liberdade de expressão" e a "liberdade de reunião". ${ }^{31}$.

- Identificar três opositores ao regime salazarista ${ }^{32}$.

Outras actividades de aprendizagem pressupõem uma interpretação e análise dos documentos:

27 É o caso dos temas "Sociedades recolectoras e as primeiras sociedades produtoras", "A Europa do século VI ao século IX", "Absolutismo e Mercantilismo numa Sociedade de Ordens" e "A grande crise do capitalismo nos anos 30". Vide Currículo Nacional do Ensino Básico. Competências Essenciais, Lisboa, Ministério da Educação, Departamento da Educação Básica, 2001, pp. 102 - 103.

${ }^{28}$ É o caso do tema "A Revolução Soviética". Vide Currículo Nacional do Ensino Básico. Competências Essenciais, Lisboa, Ministério da Educação, Departamento da Educação Básica, 2001, p. 103.

${ }^{29}$ Vide Programa História, Plano de Organização de Ensino-Aprendizagem, Ensino Secundário, 3. a edição, Lisboa, DGEBS/INCM, 1995 e Programa História, Plano de Organização de Ensino-Aprendizagem, Ensino Básico, $3^{\circ}$ Ciclo, volume II, 3. a edição, Lisboa, DGEBS/INCM, 1994.

${ }^{30}$ Natércia Crisanto, Assunção Seiça, José Amado Mendes, Novo História 9, 1.a ed., Porto, Porto Editora, 1997, p. 139.

${ }^{31}$ Fátima Costa, António Marques, História e Geografia de Portugal 6. ${ }^{\circ}$ ano, Porto, Porto Editora, 2005 , p. 115.

${ }^{32}$ Ana Rodrigues Oliveira, Arinda Rodrigues, Francisco Cantanhede, História e Geografia de Portugal 6. ${ }^{\circ}$ ano, volume 2, Lisboa, Texto Editora, 2005, p. 33. 
- Com base no documento 4 responder: quantos dias demorou, aproximadamente, o interrogatório feito pela PIDE à presa Maria da Conceição? A que meios recorreu a PIDE para obrigar a presa a falar? ${ }^{33}$

- Analisar o doc. 1 e extrair conclusões ${ }^{34}$.

- Comentar os versos do doc. $1^{35}$.

Outro tipo de temáticas apela à aplicação de conhecimentos na interpretação de documentos escritos ou iconográficos:

- Interpreta [a partir do documento 5] o significado das propostas do general Spínola no respectivo contexto histórico ${ }^{36}$.

- Confrontar [a partir do documento 8] as propostas do governo norte-americano com a posição do governo português ${ }^{37}$.

São sugeridas pequenas tarefas de pesquisa ${ }^{38}$, a recolha de testemunhos orais ${ }^{39}$ e a organização de debates ou exposições ${ }^{40}$.

Nos manuais analisados, no entanto, os documentos escritos e iconográficos não estão, na maioria dos casos, devidamente contextualizados e não fornecem pistas suficientes para guiar e facilitar a sua análise por parte dos alunos. Claro está, que isso acontece, porque os autores dos manuais se limitam, muitas vezes, a uma simples legendagem, mais escassamente, à sua datação e, só muito raramente, à especificação da sua origem ou proveniência. Com frequência, a mesma imagem é usada por mais que um manual, o mesmo acontecendo com os mapas, gráficos, cartazes e cronologias. Assim sendo, a imagem tem, frequentemente, uma função mais ornamental do que pedagógica.

${ }^{33}$ Fátima Costa, António Marques, ob. cit., p. 115.

${ }^{34}$ Natércia Crisanto, Assunção Seiça, José Amado Mendes, ob. cit., p. 253.

35 Eliseu Alves, Eugénia Cunha, Maria Cândida Ferrão, Rui Leandro Maia, História 9, 1.a ed., Porto, Porto Editora, 2000, p. 183.

${ }^{36}$ Margarida Mendes de Matos, Maria Eugénia Reis Gomes, Ana Maria Leal de Faria, Joaquina Mendes Pereira, História 12..$^{\circ}$ ano, 2. ${ }^{\circ}$ volume, 1. ${ }^{\mathrm{a}}$ ed., Lisboa, Texto Editora, 1998, p. 241.

37 Idem, ob. cit., p. 190.

38 "Recolhe informações sobre a emigração numa região do País (aquela onde vives ou outra): número de emigrantes nos últimos 40 anos; países de destino, dificuldades e benefícios trazidos à região pela emigração; influência dos emigrantes nos hábitos, na língua, na habitação, etc.; regresso definitivo dos emigrantes. Podes, com os resultados obtidos, fazer um trabalho, individual ou em grupo." Vide Maria Emília Diniz, Adérito Tavares, Arlindo M. Caldeira, História 9, 1. a ed., Lisboa, Lisboa Editores, 2004, p. 229.

39 "Estás a estudar a história recente. Podes facilmente recolher testemunhos orais sobre este período, pois existem ainda muitas pessoas que viveram estes acontecimentos. Utilizando um gravador, entrevista algumas dessas pessoas sobre os tempos do salazarismo e, depois, se o teu professor estiver de acordo, passa na aula uma selecção das gravações recolhidas e comenta-as com os teus colegas.” Vide Idem, ob. cit., p. 232.

40 "A maior parte dos portugueses do sexo masculino que têm hoje entre 45 e 60 anos estiveram na guerra colonial. [Podem] organizar um debate ou uma exposição sobre este tema. Vide Idem, ob. cit., p. 237. 


\section{Fontes}

ALVES, Eliseu, CUNHA, Eugénia, FERRÃO, Maria Cândida, MAIA, Rui Leandro, História 9, 1. ${ }^{\mathrm{a}}$ ed., Porto, Porto Editora, 2000.

BArreirA, Aníbal, MOreirA, Mendes, Páginas do Tempo 9, 1.ª ed., Porto, Edições Asa, 2003.

BARreIRA, Aníbal, MOREIRA, Mendes, Rumos da História 9, 2.a ed., Porto, Edições Asa, 2004.

COSTA, Fátima, MARQUES, António, História e Geografia de Portugal 6. ${ }^{\circ}$ ano, Porto, Porto Editora, 2005.

COUTO, Célia Pinto do, ROSAS, Maria Antónia Monterroso, O Tempo da História 12, volume 2, Porto, Porto Editora, 2003.

CRISANTO, Natércia, SEIÇA, Assunção, RODRIGUES, A. Simōes, MENDES, J. Amado, Novo História 9. ${ }^{\circ}$ Ano, Porto, Porto Editora, 1997.

CRISANTO, Natércia, SIMŌES, Isabel, MENDES, José Amado, Olhar a História 9, 1.a ed., Porto, Porto Editora, 2005.

DINIZ, Maria Emília, TAVARES, Adérito, CALDEIRA, Arlindo M., História 9, 1.a ed., Lisboa, Editorial O Livro, 2000.

DINIZ, Maria Emília, TAVARES, Adérito, CALDEIRA, Arlindo M., História Nove, 1.a ed., Lisboa, Lisboa Editores, 2004.

MAIA, Rui Leandro (coord. de), História 9, 1. a ed., Porto, Porto Editora, 2004.

MATOS, Margarida Mendes de, GOMES, Maria Eugénia Reis, FARIA, Ana Maria Leal de, PEREIRA, Joaquina Mendes, História $12 .^{\circ}$ ano, $2 .^{\circ}$ volume, $1 .^{\mathrm{a}}$ ed., Lisboa, Texto Editora, 1998.

NEVES, Pedro Almiro, MAIA, Cristina, BAPTISTA, Dalila, Clube da História 9, 1.a ed., Porto, Porto Editora, 2001.

NEVES, Pedro Almiro, MAIA, Cristina, BAPTISTA, Dalila, AMARAL, Cláudia, Novo Clube de História 9, parte 2, 1. ${ }^{\mathrm{a}}$ ed., Porto, Porto Editora, 2004.

NEVES, Pedro Almiro, PINTO, Ana Lídia, CARVALHO, Maria Manuela, História 12. Tempos, Espaços e Protagonistas, volume 2, Porto, Porto Editora, 2001.

OlIVEIRA, Ana Rodrigues, RODRIGUES, Arinda, CANTANHEDE, Francisco, História e Geografia de Portugal 6. ${ }^{\circ}$ ano, volume 2, Lisboa, Texto Editora, 2005.

PINTO, Ana Lídia, COUTO, Célia Pinto do, NEVES, Pedro Almiro, Temas de História 12, volume 2, Porto, Porto Editora, 1999.

REBELO, Carlos, Lopes, António, Olhar a História 9, 1. a ed., Lisboa, Didáctica Editora, 1999.

RIBEIRO, Avelino, SOARES, Olívia, Caminhos da História - $12 .^{\circ}$ ano, Porto, Edições Asa, 2004. 